Indonesian Journal of EFL and Linguistics

Vol. 5 No. 1, 2020

eISSN: 2503-4197, pISSN: 2527-5070

www. indonesian-efl-journal.org

\title{
Transitivity Analysis of Jokowi and Prabowo Campaign Speech in Indonesian Presidential Election 2019
}

\author{
Khairani Ade Guswita \\ Applied Linguistics Program \\ Universitas Negeri Yogyakarta \\ Suhardi \\ Applied Linguistics Program \\ Universitas Negeri Yogyakarta
}

Corresponding Author: khairaniadeguswitalubis@gmail.com

\begin{abstract}
:
This study of the transitivity system aims to identify and describe the type of transitivity, namely the process, participant, and circumstance which appeared in Jokowi and Prabowo campaign speech in 2019. The method used was qualitative method and researcher as key instrument in this study. The method used in collecting data was Metode Simak which proposed by Sudaryanto (2018). Data collected were analyzed by using the theory of Halliday (1985), namely Systemic Functional Linguistics (SFL) which focused on transitivity system. The results of the study based on data analysis show that there are 24 data or about 32\% material process as dominant process that found in Jokowi campaign speech, the most dominant participant is actor that found about $15.1 \%$ or 23 data, and time as the most dominant of circumstance that found about 21.4\% or 9 data. Whereas in Prabowo's campaign speech found that the most dominant process that used is material process about $37.5 \%$ or 30 data with the most dominant participant, namely actor and goal that have the same amount of data about 28 data or $18.2 \%$, the circumstance type which is the most dominant used namely place about 11 data or $26.8 \%$. The most dominant transitivity process used by the two Indonesian Journal of EFL and Linguistics, 5(1), 2020


presidential candidates shows that the two presidential candidates try to convey things related to the activities or actions that will be done by each presidential candidate if they are elected to become president of Indonesia in 2019-2024 period.

Keywords: campaign speech, systemic functional linguistics, transitivity

\section{INTRODUCTION}

The use of language in an oral form can be realized by speech. Speech is defined as the expression of thoughts in the form of words that are addressed to many people or discourse that are prepared to be spoken in front of the audience. In addition, the function of language as a tool for social integration can be applied by delivering a speech. Language as a means of communication, further allows each person to feel himself bound by the social group that he get in and can carry out all social activities by avoiding as far as possible the clashes to get the highest efficiency (Keraf, 1994). Basically, the objectives of speech are to convey information, convince and influence attitudes, and also entertain the listeners. The example of a speech that contains efforts to encourage, convince, and invite listeners to do something is a political speech during the campaign. In giving speech, especially in political speech people carry out their duties and the functions of their respective parties. The relationship between language and politics stems from the fact that language can be thought as a source which is drawn up to achieve socio-political goals. Vand Dijk (1997) states that each speech delivered by a politician is a realization of his intention and has its own function. Moreover, political speeches are supposed to increase the population's political participation, help them to understand important issues and how a problem is solved as well as a way for the politicians to persuade others to have the same opinion as them. Therefore, the researcher is interested to analyze the use of language in political speech.

Schiffrin (1994) defines discourse as language use depends upon broader assumptions about the relevance of language to meanings, activities, and systems outside of discourse itself. The analysis of discourse, as Brown \& Yule (1983) explain that the analysis of language is important to use. Discourse analysis is the study of written and spoken language psychological and social context, which looks at both language form and language function and also includes the study of both spoken interaction and written texts (McCarthy \& Carter, 2001). A functional systemic approach is one of the linguistics approaches that can be applied in discourse analysis. Halliday (1985) states that Systemic Functional Linguistics (SFL) is a theory that finds the language as a system and tries to explain the arrangement of languages in terms of its usefulness. Moreover, the goal of discourse analysis in Systemic Functional Linguistic (SFL) is to build a model that places texts in their social contexts and looks comprehensively at the resources that both integrate and situate them (Martin, 2015).

This study focused on the functional approach that analyzes language use. In general, this approach is intended to reveal many choices that language users have and show their meaning in interaction (Gerot \& Wignell, 1994). It also describes how the structures 
contained inside it, construct meaning and make clauses the most important unit. Halliday (1985) states that verbs are analyzed based on three components which known as "transitivity system", so it is not only seen whether need or not the verb is followed by the object. In systematic functional, transitivity is a reflection of human recognition both written and oral form in the lexicogrammar level with choice of types of process, participant elements and circumstance elements (Yuqiong \& Fengjie, 2018).

Transitivity system describes the experiences as a type of process that have relation with participant element and circumstance element. Transitivity can shows how human describe experiences based on the reality that occurs around them and within themselves (Zhang, 2017). Moreover, Eggins (2004) states that transitivity is related to the choice of the type of process and the role of the participant that is realized into the reality of experience. A clause can represent some types of process which aimed to describe how someone do something and by whom or to whom the activities are done. The reason for choosing the object of this research is the researcher want to compare and universalize Halliday's theory in Indonesian discourse which assumes that English in general often shows three domination processes namely material, relational and mental processes (Halliday \& Matthiessen, 2014).

As we know that every people have special characteristics in delivering speech. Some national figures who are very influential in delivering speech are the two Indonesian presidential candidates at 2019-2024 period, namely Joko Widodo and Prabowo Subianto. These two presidential candidates have their own characteristics. It is not only about his fashion style, leadership style, but also have their own characteristics when deliver speech to society. The campaign speech delivered by the two presidential candidates certainly has many differences, especially from the use of language that used to attract the supporters to choose him become president. Even some of the speeches delivered by them became a controversy especially on social media and became the most talked about by all people. The presidential election is the biggest democratic party that is only held once every 5 years. The interesting thing is that the presidential candidates who participated in the presidential election this year are the same as in 2014, namely Joko Widodo and Prabowo Subianto. This grand campaign event is also the biggest campaign ever that held in Indonesia. Therefore, the campaign speech have been prepared well by the two presidential candidates. In addition, the purpose of the speech is to convey the vision and mission of each presidential candidate when he is elected to become president of the Indonesian. Therefore, researcher is interested to identify and describe the type of transitivity namely process, participant and circumstance that are contained in Prabowo's and Jokowi's campaign speech.

\section{RESEARCH METHODOLOGY}

The type of method used in this study was a descriptive qualitative method. This method is a research process and understanding based on methodology that investigates a social phenomenon and human problems, emphasizes the nature of reality that is socially awakened, and the close relationship between the researcher and the subject that is 
observed. This method aims to explore and understand the meanings that are considered by a number of individuals or groups of people that is originated from social or human problems (Cresswell, 2014).

In qualitative research, researcher as a key instrument that have function to determine the focus of research, choose informants as sources of data, conduct data collection, assess data quality, analyze data, interpret data and make conclusions on their findings. The focus of research is needed in a study. Data collected were analyzed by using the theory of Halliday (1985), namely Systemic Functional Linguistics (SFL) that focused on transitivity system. Data of this study were clauses that identified by type of transitivity (process, participant, and circumstance). The source of the data in this study were Jokowi and Prabowo's campaign speech 2019.

The method used to collect data in this study was Metode Simak that used to obtain data by listen to the use of language. Sudaryanto (2018) states that Metode Simak have several techniques. This study used Teknik Simak Bebas Libat Cakap and Teknik Lanjutan, namely recording technique and note-taking technique. Sudaryanto (2018) states that in Teknik Simak Bebas Libat Cakap, the researcher is not involved in dialogue, conversations, or speeches, so the researcher does not get involved in the conversation process of people who talk to each other. This technique was used by watching and review Jokowi and Prabowo campaign speech that taken from Youtube. After that, the process of determining Jokowi and Prabowo's campaign videos by paying attention to the needs of the study, namely Jokowi and Prabowo's campaign speeches that were full from beginning until the end. The next technique was the recording technique by downloading Jokowi and Prabowo's campaign speeches videos from Youtube. The last technique was the note-taking technique which done by transcribing data and mark clauses that identified as types of transitivity systems (processes, participants, and circumstances).

\section{FINDINGS}

Based on the results of data obtained from Jokowi and Prabowo's campaign speech analysis, there are 148 data that can be analyzed based on Systemic Functional Linguistics (SFL) theory. In this research, data of transitivity is described deductively with details and the number of processes contained in each content of campaign speech that is delivered by each presidential candidate. Then, identify the most dominant process and it is followed by participants, and circumstance.

\subsection{Process}

Process is the flow of an action, event, or condition that is realized by verbs or group of verb. Process is a function that shows activities, circumstances, or conditions. (Halliday \& Matthiessen, 2014, p.220). The six types of process are described as follows.

\subsubsection{Material}

Material process is activity, creation, and events process. Material process is an activity that involves something related to physical and real action that done by the subject. 
Material process indicates that an entity do an activity and it can be continued or imposed to another (Halliday \& Matthiessen, 2014, p.224). The first participant in the material process is called an actor while the second participant is called as the goal.

(1) Saya mengajak kita untuk datang ke TPS dengan baju putih. (Jokowi)

\begin{tabular}{|l|l|l|l|l|}
\hline Saya & mengajak & kita & untuk datang ke TPS & dengan baju putih \\
\hline I & invite & us & $\begin{array}{l}\text { to come to Polling } \\
\text { Station }\end{array}$ & by wearing white clothes \\
\hline Actor & Process: material & Goal & Circumstance : purpose & Circumstance : means \\
\hline
\end{tabular}

The example (1) above shows that material process is that do activity "invite" that followed by participant. The first participant is "I" and the second participant is "us". Thus, the example (1) above is a clause that shows the actor carry out an activity or action. The action that was done in the context above is Jokowi invited Indonesian who were present at Gelora Bung Karno stadium to come to the polling station together by wearing white clothes. It is because the presidential candidate's clothes to be chosen in the election use white clothes as his trademark.

(2) Saudara-saudara datang kesini dari tempat yang jauh. (Prabowo)

\begin{tabular}{|l|l|l|}
\hline Saudara-Saudara & datang & kesini dari tempat yang jauh \\
\hline The comrades & come & here from far place \\
\hline Actor & Process: material & Circumstance: extent, distance \\
\hline
\end{tabular}

Example (2) above is a clause that shows actor do an activity or action. The material process is indicated by the presence of a word which followed by the first participant, namely "The comrades". Thus, example (2) above is a clause contains process material. The activities or actions carried out based on the example above are Indonesian from several cities in Indonesia who came to Gelora Bung Karno stadium since evening and even they joined to pray together in the morning. The action or activity carried out is the arrival of Prabowo's supporters to Gelora Bung Karno stadium. In this case, Prabowo expressed his admiration for his loyal supporters who have been waited for him for some hours.

\subsubsection{Mental}

Mental process is process that reveal human activities that involve the senses, perceptions, cognitions, desires, and emotions. Desire in the form of wishful thinking that concerns to mental or psychological aspects of life. Mental process occurs in humans and related to mental of life. Mental processes can involve more than one participant. In this case, the mental process has two parts, the first being human or like a conscious human who has the sense of seeing, feeling, and thinking. Participants who have these senses are called senser. The second participant can be in the form of objects or facts which are sensed participants called phenomenon (Halliday \& Matthiessen, 2014, p.245). 
(3) Kita ingat bahwa ideologi negara kita adalah Pancasila, Bhineka Tunggal Ika, dan UUD 1945. (Jokowi)

\begin{tabular}{|l|l|l|}
\hline Kita & ingat & $\begin{array}{l}\text { bahwa ideologi negara kita adalah Pancasila, } \\
\text { Bhineka Tunggal Ika, dan UUD 1945 }\end{array}$ \\
\hline We & remember & $\begin{array}{l}\text { that the ideology of our country are Pancasila, } \\
\text { Bhineka Tunggal Ika, and The 1945 State } \\
\text { Constitution of the Republic of Indonesia }\end{array}$ \\
\hline Senser & Process: mental & Phenomenon \\
\hline
\end{tabular}

Example (3) shows the mental process of word "remember" which is a process related to the activities of cognition and the region which is still in the mind. Clause that contain mental process occurred in humans themselves that are shown as a manifestation of subject cognition, the first participant is "We" and the second participant is called as a phenomenon. Jokowi delivered his speech which contained sentences or special greetings representing each city. This shows many differences and diversity possessed by the Indonesian who must continue to be cared for. The use of the word "remember" in the example above is a mental process that aims to give awareness to the listener what is the ideology of the Indonesian nation that might be still forgotten by Indonesian.

(4) Kami bisa merasakan getaran hati rakyat Indonesia. (Prabowo)

\begin{tabular}{|l|l|l|}
\hline Kita & bisa merasakan & getaran hati rakyat Indonesia \\
\hline We & can feel & the thrill of Indonesian \\
\hline Senser & Process: mental & Phenomenon \\
\hline
\end{tabular}

Example (4) above shows a mental process that is characterized by the word "feel". This word is a manifestation of the subject's affection or the first participant, namely "We". The second participant which is a phenomenon that is the thrill of the hearts of the Indonesian. It shows clause that contains mental process clause occurred in humans themselves. The word of "feel" is conveyed during his campaign speech because Prabowo had traveled around Indonesia for eight months and listened to the hearts and aspirations of the Indonesian who wanted a change in the country.

\subsubsection{Relational}

Relational process is a type of process that have function to connect an entity to another (Halliday \& Matthiessen, 2014, p.259). Relational process can be in the form of a relationship between one entity and another entity which is called an attribute, and can also be a relationship between an entity and its environment called an identification relationship.

(5) Modal besar untuk Indonesia maju adalah rasa optimis yang besar. (Jokowi)

\begin{tabular}{|l|l|l|l|}
\hline Modal besar & untuk Indonesia maju & adalah & $\begin{array}{l}\text { rasa optimis yang } \\
\text { besar }\end{array}$ \\
\hline
\end{tabular}


Transitivity Analysis of Jokowi and Prabowo Campaign

\begin{tabular}{|l|l|l|l|}
\hline Big capital & $\begin{array}{l}\text { for advancement of } \\
\text { Indonesia }\end{array}$ & is & $\begin{array}{l}\text { great sense of } \\
\text { optimism }\end{array}$ \\
\hline Token & Circumstance: purpose & Process: relational & Value \\
\hline
\end{tabular}

In example (5), there is relational process like the word "is". The relational process has function to connect two entities, namely the first participant and the second participant. Example (5) above shows a relational relationship and identification. Identification relationship will always be labeled with the relationship between token and value. In his speech, Jokowi conveyed that the main capital for advancement of Indonesia is a great sense of optimism. Jokowi invited the Indonesian not to feel pessimistic because there were no developed countries whose people were pessimistic.

(6) Saya menjadi letnan jendral karena rakyat Indonesia. (Prabowo)

\begin{tabular}{|l|l|l|l|}
\hline Saya & menjadi & letnan jendral & karena rakyat Indonesia \\
\hline I & become & lieutenant general & because of Indonesian \\
\hline Carrier & Process: relation & Attribute & Value \\
\hline
\end{tabular}

Example (6) above shows the existence of relational process. The word "become" indicates that the word is a relational process that has function to connect two entities, namely "I" as the first participant and "Lieutenant General" as the second participant. The valence between relational process and participation has different labeling. Attributive relationships will always be labeled with carrier and attribute. In this case, Prabowo was the lieutenant general. He stated that he would not be able to become a lieutenant general without support by Indonesian.

\subsubsection{Behavioral}

Behavioral process is a process that shows physiological activity that states the physical behavior of an entity, in this case is human. The behavioral process can only bind by a participant. Participant in this process is called behavior. The behavior process only relates to human physical activities that are concerned with or concern to themselves (Halliday \& Matthiessen, 2014, p.301). Participant in this process is called behaver.

(7) Kalian mendengar pemimpin politik Indonesia memberi sambutan. (Prabowo)

\begin{tabular}{|l|l|l|}
\hline Kalian & mendengar & pemimpin politik memberi sambutan \\
\hline You & listen to & Indonesian political leader who give speech \\
\hline Behaver & Process: behavioral & Circumstance: purpose \\
\hline
\end{tabular}

Example (7) above shows the behavior process of listening. The behavioral process shows the physiological behavior processes related to body organs. In the example of the behavior clause above, the clause has one participant that is required to be present called behaver, namely "You". The absence of participant "You" will certainly make 
the clause's meaning unclear. In this case, Prabowo conveyed to the Indonesian that are present at the event to listen to political leaders who will give their remarks.

\subsubsection{Verbal}

The verbal process is a process that shows activities that related to information (Halliday $\&$ Matthiessen, 2014, p.304). In the verbal process there are two participants namely participant who says that are structurally called as sayer, and messages that said to be called verbiage. In addition, to participant and verbiage, there are two other participants who are labeled as receiver. Receiver is participant that receive messages or verbiage (Sinar, 2012).

(8) Saya mengucapkan terima kasih pada seluruh koalisi partai. (Jokowi)

\begin{tabular}{|l|l|l|l|}
\hline Saya & mengucapkan & terima kasih & kepada seluruh koalisi partai \\
\hline I & say & thank & to great sense of optimism \\
\hline Token & Process: verbal & Verbiage & Receiver \\
\hline
\end{tabular}

In example (8) above, each unit of experience has a verbal process, namely "say". The verbal process in example (8) is valence with two participants. The first participant is in the form of a human entity, namely "I" and the second participant in the form of an entity of condition on word "thank". In his campaign speech, Jokowi expressed his gratitude to all party coalitions who have supported Jokowi's victory, such as mentioning several coalition parties such as PDI, Golkar, PKB, PPP, Perindo, PSI, and etc.

(9) Saya bersumpah di hadapan kalian bahwa saya tidak akan memperkaya diri sendiri. (Prabowo)

\begin{tabular}{|l|l|l|l|}
\hline Saya & bersumpah & di hadapan kalian & $\begin{array}{l}\text { bahwa saya tidak akan } \\
\text { memperkaya diri sendiri }\end{array}$ \\
\hline I & swear & in front of you & that I will not enrich myself \\
\hline Saver & Process: verbal & Circumstance: place & Verbiage \\
\hline
\end{tabular}

In example (9) above, "swear" is unit of experience that shows a verbal process. The verbal process in example (9) is valence with two participants. The first participant is in the form of a human entity, namely "I" and the second participant in the form of an entity of condition on word "swear". In Prabowo's campaign speech, he stated that he will not enrich himself, if he is elected president of Indonesia.

\subsubsection{Existential}

Existential process is a process that expresses something exists and in English is realized through verbs like am, is, are, are, were, be, been, being and other verbs such as exist, arise or other verb that represents the existence of nouns or phrases of objects that represent participant functions as existent (Halliday \& Matthiessen, 2014, p.307).

(10) Tidak ada rakyat yang tinggal digaris kemiskinan (Jokowi) 
Transitivity Analysis of Jokowi and Prabowo Campaign

\begin{tabular}{|l|l|}
\hline Tidak ada rakyat & yang tinggal digaris kemiskinan \\
\hline There is no Indonesian & who live in the poverty dash \\
\hline Process: existential & Existent \\
\hline
\end{tabular}

Example (10) above can be seen that the existential process includes the word "there". The process of existence shows the existence of an entity which is mentioned as a participant, which is called existent. This example can be seen as an entity in the form of a human being, namely "Indonesian". The existence of the entity is explained by the process of being. In this case, Jokowi said that if he served as president of Indonesia, there would be no more people live in the poverty dash. This has been proven when he served as president for almost 5 years the unemployment rate fell from $5.9 \%$ to $5.3 \%$.

(11) Ada wartawan asing yang bertanya kepada saya. (Prabowo)

\begin{tabular}{|l|l|}
\hline Ada wartawan asing & yang bertanya kepada saya \\
\hline There is foreign journalist & who ask me \\
\hline Process: existential & Existent \\
\hline
\end{tabular}

Example (11) above shows a clause that contains existential process. It can be seen from the use of word "there". The existence of an entity is shown by the presence of participant, namely existent. The entity described in example (11) above is a human being, a foreign journalist. The presence of foreign journalists during the Prabowo campaign made him tell that there was one foreign journalist who asked him about Indonesia. Prabowo replied that corruption in Indonesia had become a disease and when he could become president, corruptors were called and asked to return money that taken by them. This shows systematically, the example clause (11) has a label to show the existence of that identity which is called existential process.

After collect data from all utterances that contain transitivity in the campaign speech which is delivered by the two presidential candidates namely Jokowi and Prabowo, then analyze the data using SFL theory which proposed by Halliday, the author found the results of transitivity analysis which can be seen in the following table.

Table 1. Process Type in Jokowi’s and Prabowo’s Speech Campaign 2019

\begin{tabular}{|l|c|c|c|c|}
\hline \multirow{2}{*}{ Process } & \multicolumn{2}{|c|}{ Jokowi's Speech } & \multicolumn{2}{c|}{ Prabowo's Speech } \\
\cline { 2 - 5 } & Number & Percentage & Number & Percentage \\
\hline Material & 24 & $32 \%$ & 30 & $37,5 \%$ \\
\hline Mental & 11 & $14,6 \%$ & 17 & $21,2 \%$ \\
\hline Relational & 23 & $30,7 \%$ & 7 & $8,7 \%$ \\
\hline Existential & 6 & $8 \%$ & 4 & $5 \%$ \\
\hline Verbal & 11 & $14,6 \%$ & 21 & $26,3 \%$ \\
\hline Behavioral & - & $0 \%$ & 1 & $1,3 \%$ \\
\hline Total & $\mathbf{7 5}$ & $\mathbf{1 0 0 \%}$ & $\mathbf{8 0}$ & $\mathbf{1 0 0 \%}$ \\
\hline
\end{tabular}




\section{Khairani Ade Guswita \& Suhardi}

Based on the table above, it can be seen the number of processes contained in Jokowi and Prabowo's campaign speeches in the 2019. In Jokowi's campaign speech, the most dominant process is material process, which amounted to 24 data or $32 \%$. It is because the content of Jokowi's speech conveys the activity that will be done if he is elected again become President of Indonesia and something that have done when he has become president since 5 years ago. The second is the relational process which appears about $30,7 \%$ or 23 data. It is because in Jokowi's speech there are many explanations regarding the relationship of his participant role. The third is mental process and verbal process. Both of these processes have the same number of occurrences as much as 11 data or $14,6 \%$ for each verbal process. The appearance of mental processes is because there are things that taken into consideration in the formation of a speech text. The last is existential process that appears as much as 6 data or $8 \%$. The existential process generally expresses an entity. Behavioral process is not found in Jokowi's campaign speech.

In Prabowo's campaign speech, the clause that contain the processes are more in number than in Jokowi's campaign speech, which amounted to 80 data. The most dominant process in Prabowo's campaign speech is material process which appears about 37,5\% or 30 data. This is because Prabowo is more inclined to convey something related to activities or actions that must be done if he can serve as president of Indonesia 2019. The second order is filled with verbal process which is as many as 21 data or $26,3 \%$. This is different from the results of the type of process in Jokowi speech campaign. It is because Prabowo makes more things that must be said directly to his audience.

Next is mental process that appears as many as 17 data or $21,2 \%$. In the campaign speech Prabowo has quite a lot of ideas that are needed to be a strong foundation in delivering his speeches in front of many people. The third process is the relational process that appears as many as 7 data or $8,7 \%$. The use of relational processes in Prabowo's campaign speech serves as a representation of ideational functions that reveal the relationship between entities. The fifth process is existential process that appears as much as 4 data or $5 \%$. The appearance of this process is only related to the existence of foreign journalists in the event. The last process that became the difference between Jokowi and Prabowo's campaign speech is the behavioral process which appears about $1,3 \%$ or 1 data. The appearance of the process in small amounts is due to the lack of use of vocabulary that occupies the behavior process category.

\subsection{Participant}

Based on the analysis of process in the clauses contained in Jokowi and Prabowo speech, it can be seen the distribution of types and percentages of participants in Jokowi and Prabowo speech that are presented in the following table.

Table 2. Participant Type in Jokowi's and Prabowo's Speech Campaign 2019

\begin{tabular}{|l|c|c|c|c|}
\hline \multirow{2}{*}{ Participant } & \multicolumn{2}{|c|}{ Jokowi's Speech } & \multicolumn{2}{c|}{ Prabowo's Speech } \\
\cline { 2 - 5 } & Number & Percentage & Number & Percentage \\
\hline Actor & 23 & $15,1 \%$ & 28 & $18,2 \%$ \\
\hline
\end{tabular}


Transitivity Analysis of Jokowi and Prabowo Campaign

\begin{tabular}{|l|c|c|c|c|}
\hline Goal & 20 & $13,1 \%$ & 28 & $18,2 \%$ \\
\hline Recipient & 11 & $7,2 \%$ & 5 & $3,2 \%$ \\
\hline Senser & 16 & $10,5 \%$ & 16 & $10,4 \%$ \\
\hline Phenomenon & 9 & $5,9 \%$ & 15 & $9,8 \%$ \\
\hline Existent & 6 & $3,9 \%$ & 4 & $2,6 \%$ \\
\hline Behaver & - & $0 \%$ & 1 & $0,6 \%$ \\
\hline Token & 14 & $9,2 \%$ & 5 & $3,2 \%$ \\
\hline Value & 11 & $7,2 \%$ & 5 & $3,2 \%$ \\
\hline Sayer & 11 & $7,2 \%$ & 21 & $13,6 \%$ \\
\hline Carrier & 9 & $5,9 \%$ & 2 & $1,3 \%$ \\
\hline Attribute & 12 & $7,9 \%$ & 2 & $1,3 \%$ \\
\hline Verbiage & 10 & $6,6 \%$ & 22 & $14,3 \%$ \\
\hline Total & $\mathbf{1 5 2}$ & $\mathbf{1 0 0} \%$ & $\mathbf{1 5 4}$ & $\mathbf{1 0 0 \%}$ \\
\hline
\end{tabular}

Table 2 above shows that the order of dominance of participants in Jokowi's speech is actor $15.1 \%$, followed by goal $13,1 \%$ which are to be the first and the second participant in process material. The next sequence is senser $10,5 \%$, token $9,2 \%$, attribute $7,9 \%$. Furthermore, there are 3 participants who have the same number namely 11 data or $7,2 \%$ of each type of participant recipient, value, and sayer. The next participant sequence is $6,6 \%$ verbiage, $5.9 \%$ phenomenon and carrier, and the least is existent participants. This is evidenced by the presentation of the least appearance of existential processes in Jokowi's speech.

In Prabowo's speech, the most dominant participants are actor and goal who have the same number of 28 or $18,2 \%$, followed by verbiage $14,3 \%$ and sayer $13,6 \%$. In this case, the verbiage as the second participant and sayer the first participant appeared quite a lot and this is in accordance with the results of the analysis of the verbal process which is in the second place. Next sequence is $10,4 \%$ senser, $9,8 \%$ phenomenon as the first participants and the second participants in the mental process. Then, followed by recipient, token, the value that each have same presentation as much as $3,2 \%$, existent $2,6 \%$, carrier and attribute $1,3 \%$, and behaver as the least participant appearing in Prabowo's speech as much as $0,6 \%$

\subsection{Circumstance}

In general, clause has elements of the process, participant, and circumstance. Circumstantial elements can be determined by identifying the types of circumstance which related to the six transitivity processes mentioned above. Halliday \& Matthiessen (2014, p. 314) states that there are nine types of circumstance in the English transitivity system, namely extent, location, manner, cause, contingency, accompaniment, roles, matter, and angle. Based on analysis contained in Jokowi's and Prabowo's campaign speeches, there are several types of circumstances that appeared as in the following table.

Table 3. Circumstance Type in Jokowi's and Prabowo's Speech Campaign 2019

\begin{tabular}{|c|l|c|c|c|c|}
\hline \multicolumn{2}{|c|}{ Circumstance } & \multicolumn{2}{c|}{ Jokowi’s Speech } & \multicolumn{2}{c|}{ Prabowo's Speech } \\
\cline { 3 - 6 } & Number & Percentage & Number & Percentage \\
\hline \multirow{2}{*}{ Extent } & Distance & - & $0 \%$ & 2 & $4,9 \%$ \\
\hline
\end{tabular}

Indonesian Journal of EFL and Linguistics, 5(1), 2020 
Khairani Ade Guswita \& Suhardi

\begin{tabular}{|c|c|c|c|c|c|}
\hline & Duration & 5 & $11,9 \%$ & 1 & $2,4 \%$ \\
\hline & Frequency & - & $0 \%$ & 1 & $2,4 \%$ \\
\hline \multirow[t]{2}{*}{ Location } & Place & 8 & $19 \%$ & 11 & $26,8 \%$ \\
\hline & Time & 9 & $21,4 \%$ & 7 & $17 \%$ \\
\hline \multirow[t]{2}{*}{ Manner } & Means & 1 & $2,4 \%$ & - & $0 \%$ \\
\hline & Quality & 1 & $2,4 \%$ & 1 & $2,4 \%$ \\
\hline \multirow[t]{3}{*}{ Cause } & Reason & 6 & $14,3 \%$ & 3 & $7,3 \%$ \\
\hline & Purpose & 6 & $14,3 \%$ & 5 & $12,2 \%$ \\
\hline & Behalf & 1 & $2,4 \%$ & 5 & $12,2 \%$ \\
\hline \multirow[t]{2}{*}{ Contingency } & Condition & - & $0 \%$ & 3 & $7,3 \%$ \\
\hline & Concession & 4 & $9,5 \%$ & 1 & $2,4 \%$ \\
\hline \multicolumn{2}{|c|}{ Accompaniment } & - & $0 \%$ & - & $0 \%$ \\
\hline \multicolumn{2}{|c|}{ Role } & - & $0 \%$ & - & $0 \%$ \\
\hline \multicolumn{2}{|l|}{ Matter } & - & $0 \%$ & - & $0 \%$ \\
\hline \multicolumn{2}{|l|}{ Angle } & 1 & $2,4 \%$ & 1 & $2,4 \%$ \\
\hline \multicolumn{2}{|l|}{ Total } & 42 & $100 \%$ & 43 & $100 \%$ \\
\hline
\end{tabular}

Based on table 3 above, it can be seen that the types of circumstance identified in Jokowi's campaign speech is 6 of 9 all the type of circumstance based on the theory of Halliday. The location aspect became circumstance dominated Jokowi's campaign speech namely $21,4 \%$, followed by other aspects which are below the presentation of time location aspects. Another aspect is the location time aspect appeared around 19\%, followed by reason and purpose that appeared around 14,3\%, duration extent $11,9 \%$, concession 9,5\%, and there are four aspect that have the same presentation namely means, quality, behalf, and angle namely $2,4 \%$.

In Prabowo's campaign speech, the most dominant type of circumstance is the location place which is equal to $26,8 \%$, followed by aspects that have a presentation below the type of circumstance location place. These aspects are around 17\%, purpose and behalf which have the same presentation is around $12,2 \%$, reason and condition $7,3 \%$, extent distance $4,9 \%$, duration, frequency, quality, concession, and angle have a number of presentation appearances the same in Prabowo's campaign speech are around 2,4\%.

\section{DISCUSSION}

This study was conducted to identify and describe the type of transitivity, namely the process, participant, and circumstance which appeared in Jokowi and Prabowo campaign speech in 2019. The present study found that the dominant process in their speech campaign was material process. It means that both presidential candidates try to convey things related to the activities or actions that will be done by each presidential candidate if they are elected to become president of Indonesia in the 2019-2024 period. The findings of this study are in line with Yuliana, Manda, \& Kamsinah (2018) study that analyzed transitivity and ideology in Donal Trump campaign speech. The result showed that material process was the most dominant process that used by Donald Trump in order to invite US citizens to improve America which considered in the worst conditions. In addition, Donald Trump often involved racial issues to achieve his goals in his campaign so that it can influence the thinking of US citizens to choose him and 
follow his views. Furthermore, the fact that political discourse entails material process corresponds with the findings by Yujie \& Fengjie (2018), Zhao \& Yi Zhang (2017), Zhang (2017), and Rachman, Yunianti, \& Ratnadewi (2017).

The findings of this study also point out that relational process was the second dominance process in Jokowi's speech campaign. It is because in Jokowi's speech there are many explanations regarding the relationship of his participant role. Meanwhile, Hemas and Aryanti (2016) found that relational process as the type of transitivity process that mostly used in Emma Watson's speech for the HEFORSHE campaign. In their study, relational process was used as the way for the speaker to define, to describe, and to classify her idea. This present study also found Prabowo used verbal process as the second dominant process in his speech campaign. Prabowo makes more things that must be said directly to his audience. Kondowe (2014) concluded that verbal processes have been used as markers of transition and topic shift. Bingu "The Third Malawian President" as the object of Kondowe's study often refers to himself as a direct sayer of verbal processes using pronoun $I$.

Moreover, this present study revealed the dominant participants were actor and goal which are the first and the second participant of the material process. By seeing the findings, the actors which were I, We, the Comrades and the Citizens often used by both presidential candidates in their speech campaign. Meanwhile, the goals which were Indonesian, Our Country, Us, and Developed Indonesia were repeatedly used in the speech. The fact that the purpose of both presidential candidate conveyed the speech campaign in order to persuade all of Indonesian chose them by giving their visions and missions as the next president of Indonesia. In addition, it indicates the order of process dominance corresponds to the order of dominance of participants. The findings of this study support the findings of Rambe (2017) who found the most dominant participants actor and goal as part of material process in Donald Trump's Speech about Radical Islamic Terrorism. This happened due to the dominant process that was used in the speech is material process.

This present study also found the most dominant circumstance was location. Jokowi used time as the dominant type of location. It means that Jokowi often conveys things related to the time where he had served as president in 2014 whereas Prabowo often utters things about the place where the campaign speech was held. Based on the findings above, it can be interpreted that Jokowi and Prabowo have their own way to convey their own ideology in gaining power. It indicates that they have ability to control people which in line with their purpose to win Indonesian's heart. Similar result also shown on research of Widodo, Mulyani, \& Santoso (2018) who described the types of transitivity (processes, participants, and circumstance) in Ahok's campaign speech in DKI Jakarta Governor Election period of 2017-2022. Material process was the dominance procees, goal was the dominance participant, and location was the dominance circumstance. The difference from this study is their study also analyzed the purpose which conveyed by Ahok in his campaign speech. They found that the context of situation in a discourse had a quite important role in analyzing the purpose that wanted to be delivered by Ahok in Indonesian Journal of EFL and Linguistics, 5(1), 2020 


\section{Khairani Ade Guswita \& Suhardi}

a campaign speech at DKI Jakarta Governor election such as realm of experience, activities, short and long term goals, social distance, social status, and so on.

Contrast between some previous study and this present study is this study compares two presidential candidates who participated in the presidential election in Indonesia while some previous study just focused on a candidate. In addition, based on the findings of this present study can be assumed that the existance of circumstances also important constituents in a text. Circumstances can help the transitivity analysis in terms of the purpose of the text or the kind of text (Suparto, 2018). It also can enrich the previous study about transitivity analysis. In contrast, a number of scholars (Ong'onda, 2016; Agbo, Ugwoke, \& Ijem, 2019) just analyzed the speech by using one of the type of transitivity namely process. Therefore, this present study completed the disscussion about all the types of transitivity by comparing two presidential candidate's speech campaign.

\section{CONCLUSION}

Based on transitivity analysis in Jokowi's campaign speech above, it can be concluded that the type of transitivity process found by the researcher consists of material process, mental process, relational process, and existential process. In Jokowi's campaign speech, material process is the highest percentage level among the other processes. The use of words such as keep, gather, assembly, build, invite, preparing that have the predicate of material process. It is caused by the speaker wants to show what has been done. The existential process is the lowest presentation level and it indicates that the speaker namely Jokowi does not explain much about the existence of a place or event. The behavioral process is not found in Jokowi's campaign speech. The most dominant type of participant in Jokowi's campaign speech is the actor who is the first participant of the material process. The existent participant is the lowest presentation level and there is no type of behaver participant. It can be concluded that the presentation of the appearance of the first and the second participants are influenced by the process that also appears in the clause. The most dominant type of circumstance is time and the least appear is the type of means, quality, behalf, and angle that have the same presentation. There are several types of circumstance that do not appear in Jokowi's campaign speech, namely accompaniment, role, and matter.

While the results of transitivity analysis in Prabowo's campaign speech shows that the types of transitivity processes found are material process, mental process, relational process, existential process, and behavioral process. The most dominant type of process in Prabowo's campaign speech is material process. The use of words such as give, prepare, come, stand, build, steal, stand that have the predicate of material processes. This is due to the speaker conveys things that related to activities or actions that must be done. The behavioral process becomes the least appearance process because the speaker uses only one vocabulary that occupies the category of behavior process. The most dominant type of participant are actors and goals that have the same presentation. The type of participant that appears the least is behaver. From the description above, the 
researcher can conclude that the order of process dominance corresponds to the order of dominance of participants. The most dominant type of circumstance in Prabowo's speech is place and the least appear are duration, frequency, quality, concession, and angle which have the same presentation.

From the results of this study, it can be concluded that in a clause represents an event or various types of process and transitivity with the aim to explain how a person takes action and by whom or to whom the action is taken. Therefore, the SFL study with transitivity analysis in Jokowi and Prabowo's campaign speeches in the presidential election in 2019-2024 period is expected to be used as a real illustration about the reconstruction of each presidential candidate when he is elected to be president and affect to listeners or supporters of each presidential candidate that are present at the event. Researcher suggests for the further study to examine the social and cultural context of speech from various types of discourse both oral and written form to enrich the insight into the application of SFL theory that related to transitivity systems.

\section{REFERENCES}

Agbo, I., Ugwoke, F., Ijem, B. (2019). Transitivity process in President Buhari's 'My convenant with Nigerians'. English Language Teaching, Vol. 12 (4): 7-14. URL: https://doi.org/10.5539/elt.v12n4p7.

Brown \& Yule. (1983). Discourse analysis. Cambridge : Cambridge University Press.

Creswell, J. W. (2014). Qualitative, quantitative, and mixed methods approaches. Sage Publication : United States of America.

Eggins, S. (2004). An Introduction to functional linguistics. London: Continuum International Publishing Group.

Gerot \& Wignell . (1994). Making sense of functional Grammar. Australia.

Halliday, M.A.K. (1985). An Introduction to Functional Grammar. Great Britain: Edward Arnold (Publisher) Ltd.

Halliday, M.A.K \& Matthiessen, C. (2014). An introduction to functional grammar (4th edition). London : Routledge.

Hemas, S., M. \& Ariyanti, L. (2016). Transitivity and ideology in Emma Watson's speech for the HeForShe campaign (Critical Discourse Analysis). Language Horizon, Vol. 4 (2): 27-37. Retrieved from https://jurnalmahasiswa.unesa.ac.id/index.php/languagehorizon/article/view/14949/13524.

Keraf, G. (1994). Komposisi. Jakarta: Nusa Indah.

Kondowe, W. (2014). Presidents and ideologies: A transitivity analysis of Bingu Wa Mutharika's inaugural address. International Journal of Language and Linguistics, Vol 2 (3): 174-180. doi: 10.11648/j.ijll.20140203.16.

Martin, J., R. (2015). Cohesion and texture. In D. Schiffrin, D. Tannen and H. Hamilton (eds.), Handbook of discourse analysis (2nd edition). Chichester, UK : John Wiley.

McCarthy, M \& Carter, R. (2001). Language as discourse: Perspective for language teaching. London: Longman.

Indonesian Journal of EFL and Linguistics, 5(1), 2020 
Ong'onda, N.,A. (2016). Transitivity analysis of newspaper headlines on terrorism attack in kenya: A case study of Westgate Mall, Nairobi. International Journal of Humanities and Social Science, Vol. 6, No. 9: 1-9. Retrieved from jhssnet.com/journals/Vol_6_No_9_September_2016/10.

Rachman, A., Yunianti, S., \& Ratnadewi, D. (2017). Critical discourse analysis in Donald Trump presidential campaign to win American's heart. Teaching of English Language and Literature Journal, Vol. 5 (2): 8-17. DOI: http://dx.doi.org/10.30651/tell.v5i2.388.

Rambe. (2017). Experiential Function in Donal Trump's Speech about radical islamic terrorism. Applied linguistic journal of Unimed, Vol. 14 (1): 59-49. Retrieved from http://jurnal.unimed.ac.id/2017/index.php/JLT-Unimed.

Schiffrin, D. (1994) . Approaches to discourse. Oxford: Basil Blackwell.

Sinar, T. S. (2012). Teori dan analisis wacana: Pendekatan linguistik sistemik fungsional. Medan: Penerbit Mitra.

Sudaryanto. (2018). Metode dan aneka tehnik analisis bahasa (Pengantar penelitian wahana kebudayaan secara linguistik). Yogyakarta: Duta Wacana University Press.

Suparto, A., D. (2018). Analisis ketransitifan dalam framing pada artikel berita online. Ranah: Jurnal Kajian Bahasa. Vol. 7 (1): 16-32. doi: https://doi.org/10.26499/rnh.v7i1.586.

Van Dijk, T., A. (1997). Discourse as structure and process (Discourse studies: A multidisciplinary introduction). London : SAGE Publication.

Widodo, D., Mulyani, M., Santoso, W. (2018). Transitivitas pidato kampanye Ahok pada pemilihan gubernur DKI Jakarta periode 2017-2022. Jurnal Pendidikan Bahasa dan Sastra Indonesia, Vol. 3 (1), 18-26. Retrieved from https://journal.stkipsingkawang.ac.id/index.php/JP-BSI/article/view/444/460.

Yujie, Z., Fengjie, L. (2018). Transitivity Analysis of American President Donald Trump's Inaugural Address. International Journal of Literature and Arts. Vol. 6 (2): 28-34. doi: 10.11648/j.ijla.20180602.11.

Yuliana, Manda, \& Kamsinah. (2018). Transitivity and ideology in Donald Trump campaign speech. Jurnal Ilmu Budaya, Vol. 6 (1): 1-13. DOI: http://dx.doi.org/10.34050/jib.v6i1.4320.

Yuqiong Z. \& Fengjie. (2018). Transitivity analysis of David Cameron's speech in retaining scotland. International Journal of Language and Linguistics, Vol, 6 (2), 70-79. doi: 10.11648/j.ij11.20180603.13.

Zhang, Y. (2017). Transitivity analysis of Hillary Clinton's and Donal Trump's first television debate. International Journal of Applied Linguistics \& English Literature, Vol.6, (7): 65-72. $\quad$ Retrieved from http://www.journals.aiac.org.au/index.php/ IJALELarticle/view/3760/3031.

Zhao \& Yi Zhang. (2017). A transitivity analysis of American President Donald J. Trump's inaugural address. International Journal of Liberal Arts and Social Science. Vol. 5 (5): 31-43. Retrieved from https://ijlass.org/data/frontImages/gallery/Vol._5_No._5/5._31-43.pdf. 